\title{
Gonçalves Dias e a Procura da Identidade Nacional Brasileira
}

\author{
Weberson Fernandes Grizoste ${ }^{1}$
}

Durante o Segundo Império a necessidade da criação de uma identidade nacional foi um assunto bastante deliberado, o país recém-independente sentia-se demasiado unido a sua antiga metrópole, os estudiosos brasileiros eram exclusivamente formados em universidades portuguesas. Sentir-se desligado de Portugal era uma necessidade urgente e por isso o Imperador patrocinou muitas atividades à procura da Identidade Nacional. A idéia do índio como elemento nacional era algo muito proeminente durante o período do Segundo Império, houve-se uma valorização da cultura indígena, muitas excursões foram levadas a cabo nesta ocasião. O Brasil parecia ter finalmente encontrado a sua origem.

A procura da Identidade Nacional passava, portanto, pela eleição de um representante nacional e o papel civilizador da literatura esbarrou na verdadeira origem brasileira: a de ser um feito português conjugado violentamente com outras duas raças, a nativa e a africana. Essa literatura autêntica exigiu a negação de tudo que viesse da metrópole, embora, como sabemos, o próprio método daquela literatura genuinamente nacional foi ditada pelos europeus. Cândido (1993: 15) denominou o processo de construção dessa identidade literária como "renovação literária". No entanto, não seríamos demais supersticiosos em perguntar que renovação literária seria esta? Já que não se pode dizer de literatura brasileira anterior, a literatura colonial é ainda negada como genuinamente brasileira, diríamos que nos idos e vindos o Brasil nutre-se de duas

\footnotetext{
${ }^{1}$ Bolsista da Fundação para a Ciência e Tecnologia - FCT, doutorando e mestre em Poética e Hermenêutica pela Faculdade de Letras da Universidade de Coimbra, Portugal. Membro do Centro de Estudos Clássicos e Humanísticos. Licenciado em Letras pela Universidade do Estado de Mato Grosso.
}

Brasiliana - Journal for Brazilian Studies. Vol. 2, n.2 (Nov 2013). ISSN 2245-4373. 
literaturas, colonial e pós-colonial. Se partirmos por esta ótica, a de não assumirmos a literatura colonial como brasileira é de questionar que "renovação literária" é esta de que anuncia Cândido.

Gonçalves Dias tem sido visto como um dos maiores construtores da Identidade Literária do Brasil. Quando é comparado com Sousândrade, Gonçalves Dias ao lado dos demais poetas, são acusados de conivência com a elite da época. De fato, quando saímos dos Poemas Americanos debruçamo-nos em Meditação, o poema prosa de Gonçalves Dias baseado em grande parte nas Considerações Econômicas sobre a Escravatura de TorresHomem, vemos o quanto a poética gonçalvina ficou comprometida. O próprio Gonçalves Dias acusou a sua impossibilidade de fazer uma verdadeira literatura e a originalidade do Meditação foi tão comprometedora que causou a sua demissão do Guanabara.

Meditação nunca foi concluído nem publicado completamente enquanto o poeta vivia. Estou convencido de que Meditação serviu de matriz para o grande projeto de uma epopeia - Os Timbiras, foi nela que o poeta primeiro anunciou-a e depois não podendo criticar a sociedade brasileira tão abertamente como fizera no poema-prosa, pôs-se a fazer lacônicamente e indiretamente na epopeia. Comparando as duas nações, o poeta lamenta que Portugal se tenha servido do Brasil como retrete, "sentina de um povo pigmeu" (Med. 3.2.10), n'Os Timbiras ele vai se lamentar por que motivo o Brasil tornouse mera imitação da Europa deixando para trás as virtudes dos primeiros habitantes - os índios.

Meditação é o retrato de uma sociedade falida, destinada à morte, prestes a sucumbir ao término de sua infância, simplesmente porque herdara da nação senhora todos os seus vícios. Essa nação senhora era a mesma que destruiu uma rica e pura civilização, descrita n'Os Timbiras, onde ele também se perguntaria pelo futuro da nação. Tendo em vista este fio de esperança que adelgaça, o poeta em Meditação, crente num 
futuro glorioso quando a nação encontraria o seu prumo e seguiria o caminho para não servir de escárnio para as demais. Podemos conjecturar que Os Timbiras não é apenas um poema de nostalgia da vida indígena, senão da esperança de uma sociedade destruída que precisa ser resgatada; por que o índio, para Gonçalves, não era apenas o instrumento do indianismo, era a própria nacionalidade, conforme ele diz:

“Eles são o instrumento passivo de quanto aqui se praticou de util ou de glorioso; são o principio de todas as nossas coisas; são os que deram a base para o nosso caracter nacional, ainda mal desenvolvido, e será a corôa da nossa prosperidade o dia da sua inteira rehabilitação." (Dias, 1968: 207)

Mas estes índios, donos de uma virtude que os europeus há muitos haviam perdido, iniciaram uma luta sanguinolenta com os homens dominadores porque não queriam ser dominados. Era a luta "- dos fortes contra os fracos - dos cultos contra os bárbaros"; uma batalha porfiada de Porto Seguro até à margem esquerda do Prata e às margens do Amazonas. "E a luta durou muitos anos, até que nas tabas das três embocaduras - um índio converso - o primeiro brasileiro que encontramos na História - cioso da liberdade em que nascera, morreu nobremente de morte ignominiosa por ordem de um Albuquerque" (Med. 3.2.24)².

Este índio aqui não nominado de acordo com Marques (2010: 227-228) era

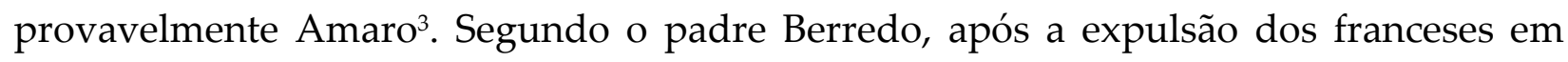

\footnotetext{
${ }^{2}$ Provável referência a uma aldeia Tupinambá, Tapuitapera, na embocadura dos três rios: Munin, Tabacuru e Meari que desaguam na Baia do Maranhão (Marques, 2010: 265). Brandão cita a conquista do Maranhão, da qual atesta Brandonio ter pouca notícia, visto que a comunicação entre os territórios do Brasil e do Maranhão era demasiado escassa nos dois primeiros séculos (Brandão, 1943: 52-53. Marques faz uma análise deste acontecimento (Marques, 2010: 224-229).

${ }^{3}$ Também de acordo com Marques (2010: 228).
}

Brasiliana - Journal for Brazilian Studies. Vol. 2, n.2 (Nov 2013). ISSN 2245-4373. 
1615, os portugueses se puseram em guerra contra os Tupinambás que favoreceram os franceses e desprezavam a colonização portuguesa; desta forma eram duas as prováveis causas desta guerra: a primeira, segundo Capistrano de Abreu, pelo fato de um branco ter roubado um venábulo, uma espada e duas mulheres do famoso cacique Pacamão, chefe que liderou uma revolta onde foram mortos setenta brancos segundo uns, cem segundo outros (Apud Marques, 2010: 227.); o segundo motivo era por causa desse índio chamado Amaro (Berredo, 1989: 186 (431)), criado com os padres da Companhia de Jesus e muito apaixonado pelos franceses, que fingindo saber ler asseverou diante dos principais que o assunto da carta do Capitão-Mor Francisco Caldeira dizia que todos os Tupinambás deviam se tornar escravos. Estas supostas palavras de Amaro foram tidas por Berredo como diabólicas, e tendo levado os Tupinambás à guerra com a resposta imediata dos Portugueses. Liderados pelos irmãos (Antonio e Mathias), filhos do então governador Jerônimo Albuquerque (1548-1618), os Portugueses entraram sertão a dentro e massacraram os índios e por ordem direta de Mathias de Albuquerque, o índio Amaro, para servir de exemplo, foi cruelmente morto à boca do canhão (Berredo, 1989: 198-199 (454)). Esta taba das três desembocaduras não deve ser outra senão Tapuitapera, a mesma citada em Os Timbiras (2.237). O brasileirismo de Amaro é garantido por Gonçalves Dias, porque esse índio foi capaz de tudo pela liberdade, e por outro lado, pela sua conversão ao cristianismo (Marques, 2010: 229).

Ainda de acordo com o Meditação, enquanto Portugal demandava com as nações indígenas, a "Europa inteligente" aplaudiu a nação marítima e guerreira que, através do oceano fundava um novo Império, embora estivesse viciando-o com o cancro da escravatura, transmitindo-lhe o amor do ouro sem o trabalho. O destino de Portugal foi a ruína, o opróbrio das gentes e da maravilha que tinha sido, porque tinha escravizado o fraco, incrédula porque tinha abusado da religião, pobre porque tinha amado de sobremaneira a riqueza. Esse vício maldito está expresso num símile feito por 
Gonçalves, segundo o qual quando os Portugueses cavavam um buraco para fincarem na terra conquistada uma cruz, encontraram uma veia de ouro que os distraiu do seu trabalho (Med. 3.2.25-33).

Foi grande e impactante a descrição que o poeta fez da sociedade brasileira em Meditação, a mais forte que tenho lido na literatura daquela época. O poeta entra num dilema que só os poetas podem sentir, o texto é um retrato que melhor demonstra a angústia que sentiu no pós-exílio, acompanhado das suas cartas a Teófilo, cheias da constrição de quem sentia saudades de Coimbra - embora dela ainda tivesse o que se queixar. O "cá" (Europa) e o "lá" (Brasil) da Canção do Exílio se repete em Meditação, onde a presença do "lá" se ouve de quem já saiu do "cá" e habita em um espaço próprio de quem ainda não chegou "lá". Mas ao sair de "cá" e ao olhar para "lá" o poeta vê mais do que se lembrava "cá", onde vira apenas a falta de beleza urbana: aldeias e cidades semelhantes as árvores raquíticas dos desertos infrutíferos, ruas tortas e mal calçadas, casas sem elegância e baixas, palácios sem beleza artística, rios cheios de jangadas e canoas pobres; uma vez "lá", vê apenas escravos por toda a parte. Em quatro versetos o poeta repete nada mais que cinco vezes a palavra "escravos", como que assustado com aquilo que vê. O poeta atribuiu toda a falta de beleza urbana à escravatura, porque a beleza era filha do pensamento e o pensamento do belo e do grande era incompatível com o sentir do escravo (Med. 1.5.4).

Mas, eis a maior das suas amarguras, o poeta mêmore das terras estrangeiras e de se ter abusado pelo fato daqueles pássaros não cantarem como os sabiás, daqueles céus terem menos estrelas e bosques menos flores; recordando tudo isso, amargurado e triste, pergunta qual seria a real percepção dos estrangeiros que aportavam ao Brasil, a terra que ele chama de pigmeus - em carta e em Meditação: 
"Por isto o estrangeiro que chega a algum porto do vasto império consulta de novo a sua derrota e observa atentamente os astros - porque julga que um vento inimigo o levou às costas d'África.

E conhece por fim que está no Brasil - na terra da liberdade, na terra ataviada de primores e esclarecida por um céu estrelado e magnífico ${ }^{4}$ !

Mas grande parte de sua população é escrava - mas a sua riqueza consiste nos escravos ${ }^{5}$ - mas o sorriso - o deleite do seu comerciante do seu agrícola - e o alimento de todos os seus habitantes é comprado à custa do sangue do escravo!

E nos lábios do estrangeiro, que aporta ao Brasil, desponta um sorriso irônico e despeitoso - e ele diz consigo, que a terra - da escravidão - não pode durar muito; porque ele é crente, e sabe que os homens são feitos do mesmo barro - sujeitos às mesmas dores e às mesmas necessidades." (Med. 1.4.12-15).

Marques pergunta se o poeta poderia criticar abertamente a escravidão - a mola sustentadora do Estado -, quando, à semelhança dos demais poetas românticos também era funcionário público (Marques, 2010: 9). A julgar pela carta a Teófilo ${ }^{6}$ já em 1860 podemos afirmar com segurança que não era possível, apesar de que certos elementos

\footnotetext{
${ }^{4}$ Sobre este fato, Maximiliano, principe de Wied-Neuwied, quando esteve no Brasil entre os anos de 1815 a 1817 , escreveu sumariamente sobre a cidade do Rio de Janeiro, atestando que, com a chegada de cerca de 20 mil portugueses, a então pequena cidade do Rio sofreu uma grande transformação e acabou por adotar costumes muito europeus; mas que o estrangeiro recém-chegado se surpreendia com o grande número de negros e mulatos que se podia encontrar nas ruas, porque a população da cidade contava com maior número de negros e homens de côr do que de brancos (Maximiliano, 1958: 23-24).

${ }^{5}$ Desde o princípio o escravo tornou-se um negócio importante, conforme atesta Brandão (1943: 99) nos seus diálogos, ao testemunhar que todos os moradores do Brasil viviam, tratavam e trabalhavam com a gente vinda da Guiné ("África”).

6 "Quando me lembrar de mandar à fava os grandalhões da nossa terra já começo a antever a possibilidade de fazer alguma cousa com a literatura. Será um exemplo excelente; porque enquanto o literato carece de empregos públicos - não pode haver literatura que mereça tal nome.” (carta a Teófilo, 1860, Mar. 18).
}

Brasiliana - Journal for Brazilian Studies. Vol. 2, n.2 (Nov 2013). ISSN 2245-4373. 
da crítica apresentada no século XX insistiram em dizer que $\operatorname{sim}^{7}$. Obviamente que Meditação só existe porque Gonçalves Dias ainda desconhecia a política de imprensa brasileira; ao vê-lo embargado no Guanabara o poeta sentiu-se coagido a apresentar um tipo de literatura que agradasse aos grandalhões da terra. Ao que parece, Meditação cumpriu às riscas estes interesses, sendo provavelmente digerida em silêncio bem longe dos debates da imprensa, porque implicaria uma discussão indesejada que norteava a política excludente da sociedade brasileira oitocentista (Marques, 2010: 265).

Ao lermos o Meditação vemos surgir novamente a questão da eleição do índio, a escolha do índio como elemento da terra estava para além da literatura. Sodré (1969: 256) acha estranho que a catequese, um fenômeno contemporâneo, e que seria a parte complementar das descobertas e conquistas ultramarinas, tenha ignorado ao problema da escravatura dos negros africanos, embora protestassem veementes, de forma singular, contra a escravidão dos indígenas americanos (Sodré, 1969: 257); destaca ainda que desde cedo o índio mereceu tratamento especial, um conceito especial, um lugar especial. Se atentarmos para o Meditação e como as coisas se sucederam, saberemos por que razão o negro poderia pertencer a literatura: louvar o negro numa sociedade escravocrata em que ele era a principal vítima seria uma heresia; aliás, a tal revista Nitheroy de 1836, a quem muitos atribuem o surgimento do indianismo no Brasil é que trouxe as chamadas Considerações economicas sobre a escravatura, de Torres-Homem; não é novidade para a crítica literária que a tal revista não tenha passado do primeiro número, além disso ela foi publicada em Paris (aliás, era no exterior que se praticava a crítica). Não será preciso dizer que o mesmo motivo que impediu Meditação de ser publicado na sua totalidade foi o mesmo que terá impedido a continuidade da revista Nitheroy. Na

\footnotetext{
${ }^{7}$ Quanto a isto, num famoso livro recentemente publicado, o Guia politicamente incorreto da História do Brasil, o autor insiste em afirmar (utilizando como fonte Dom Pedro II de José Murilo de Carvalho) que durante o Segundo Império o Brasil experimentou uma liberdade de imprensa que foi perdida com proclamação da República e só gradualmente foi sendo alcançada com muito esforço da população (Narloch, 2011: 268-291).
}

Brasiliana - Journal for Brazilian Studies. Vol. 2, n.2 (Nov 2013). ISSN 2245-4373. 
verdade, a eleição do índio pelos Românticos, a sua escolha não encerrou nenhuma originalidade, por que não traduziu uma posição angariada no século XIX, mas fundamentalmente alicerçado no tempo, pra além da influência estrangeira no problema do indianismo. Para Melatti (1987: 195), o índio nascido no Brasil depois da posse portuguesa não deixa de ser brasileiro, todavia não é mais brasileiro que o negro e o branco que colonizaram a terra; antes que o Brasil se formasse, os indígenas estavam aqui, o Brasil se formou à custa das conquistas dos territórios desses povos. Aqueles que não morreram tiveram que se submeter. As palavras de Coutinho (1969: 69) expressam muito bem como se deu o processo civilizador no Brasil:

“O português fica encantado com o nosso índio, que lhe pareceu pitoresco e irá escravizá-lo na colonização. Polígamo por excelência, gostou mais da índia, que esta, sim, lhe aguça a concupiscência desde o primeiro instante, com as suas 'vergonhas tão cerradinhas' e demais encantos. Ou porque a nudez, já lhe fosse um afrodisíaco, um convite irrecusável, ou porque fizesse de conta que ela era a 'moura encantada', o caso é que a mulher do mato lhe pareceu mais bonita, mais apetitosa que a do reino."

Não havia qualquer noção de Brasil antes da descoberta dos portugueses, sendo assim é impossível falar de brasilidade nesse período, Souza Pinto dá-nos um claro exemplo daquilo que motivou a construção do indianismo como identidade nacional, no velho mundo o grande elo que prende os homens é o fator do sangue nacional. Gonçalves (1998: 1074) dá claros exemplos disso quando afirma não ter "sangue azul". Já na América, o que determina a nacionalidade deixa de ser a raça e passa a ser a terra; ou seja, o que nasce lá lhe pertence, se lá habita; portanto quem vive na América é 
americano (Souza Pinto, 1931: 12). Ao optar pelo índio como elemento nacional, Gonçalves Dias fê-lo porque traduziu para a América o conceito de nacionalismo difundido na Europa, e ainda alheio aos americanos. o exemplo mais claro da verdadeira brasilidade está expresso em Marabá, por que para Fernandes (1989: 139), o poema retrata o surgimento de uma nova raça, a mestiçagem. Mas o que poderia ser o fator de preciosidade literária em Gonçalves é motivo de depreciação, porque Marabá não é um poema de exaltação a mestiçagem, mas de lamento e desesperação pela condição diante da pureza de raça perdida.

Gonçalves Dias deixa, por assim dizer, de cantar o negro numa época em que os "homens de pensamento" pretendiam erguer o índio à categoria de padrão humano, enquanto omitia tudo o que diminuía o próprio branco, ou o negro tirado do seu lar para o labor agrícola e mineiro (Sodré, 1969: 265). Na tentativa de enaltecer o índio Gonçalves demonstra a voracidade da ambição do europeu, mas em nenhum momento destaca que estes, pra além de matar o índio como afirma, arrebataram o negro do seio familiar, para alimentar a máquina de sua empresa. Ainda de acordo com Sodré (1969: 268) um estudioso moderno refletiu que o negro não poderia ser tomado como assunto e muito menos como herói, porque foi submisso, passivo, conformado em vez de altivo, corajoso, orgulhoso; ao passo que o indígena preferia morrer a submeter-se a

O índio desde cedo ocupou o seu lugar na literatura, basta vermos na carta de Caminha o interesse que o selvagem americano despertou nos portugueses, mas é Basílio da Gama que Souza Pinto (1928: 8) enxergou como um dos precursores não apenas do Brasil, mas do Novo Mundo daquilo que era a verdadeira poesia americana; no entanto não a reconhece como uma epopéia, mas uma alma revoltada e profética em que a primeira afirmação definitiva do ideal americano é diversa do europeu (Souza Pinto, 1928: 9). Porém, para Sodré (1969: 264) os precursores da literatura, ao utilizarem o índio, como Santa Rita Durão e Basílio da Gama, fizeram dele um assunto e tomaram 
para modelo os mestres europeus. Os indianistas por sua vez, tentaram fazer do índio mais que um assunto; tentaram transformá-lo num herói. Sodré destaca ainda que ninguém quisesse trazer o índio para criação literária, ainda que fosse apenas como assunto. Segundo Machado de Assis (1962/1994: 802), estes poetas buscaram ao redor de si os elementos de uma poesia nova e deram os primeiros traços da fisionomia literária do Brasil. As mesmas obras de Basílio da Gama e Durão quiseram antes ostentar certa cor local do que tornar independente a literatura brasileira, literatura que não existe ainda, que mal poderá ir alvorecendo agora (Assis, 1962: 802). Houve depois uma espécie de reação. Entrou a prevalecer a opinião de que não estava toda a poesia nos costumes semibárbara anteriores à nossa civilização, o que era verdade, - e não tardou o conceito de que nada tinha a poesia com a existência da raça extinta, tão diferente da raça triunfante, - o que parece um erro (Assis, 1962:802).

Durante séculos as narrativas de viajantes foram definindo a América, tanto para valorizar o paraíso de exuberância e de fertilidade, quanto para criticar a ausência de civilização, através da negação relativamente à Europa. $\mathrm{O}$ indianismo surge, portanto com o interesse de inverter esta perspectiva, passa a definir-se afirmativamente diante de tudo que a Europa não é (Rounat, 1991: 252). Um passado mítico e lendário, sobretudo histórico, a medida que as nações européias remontam de uma época medieval, nesta ocasião os nossos primitivos construíam também uma história de glória; "nós também temos nossos mitos: gênios dos rios, lagos, matas, montes e vales", de acordo com Cândido (1993: 20) isto é a tendência que define um desejo de individuação nacional. Para Cândido (1993: 22) o Indianismo não quer redefinir apenas a atitude poética, mas o próprio lugar do homem no mundo e na sociedade.

Segundo Cândido (1993: 16) os poetas da segunda geração manifestavam remorso ao sobrepor os problemas exclusivamente pessoais, ou ao abandoná-los pelos temas universais e o cenário de outras terras. Álvares de Azevedo é o menos pitoresco de 
todos e o mais obcecado pelos seus dramas íntimo e os modelos europeus. Em Macário, peça teatral escrita pouco antes de sua morte e logo após ter sonhado um encontro seu com satã, há um importante trecho em que desdobra nos personagens, enquanto um acusa ou outro defende-se, um poeta cético e pouco nacional, que certamente é ele próprio. Macário aparece censurando a artificialiade do indianismo e da poesia americana, numa revolta de bom senso realista. Ele critica os romanticos de falarem dos gemidos da noite no sertão, das tradições das raças perdidas das florestas, das torrenes das serranias, como se lá tivessem dormido ao menos uma noite, como se acordassem procurando túmulos, e perguntando como Hamlet no cemitério a cada caveira do deserto o seu passado. Esquecem-se talvez de contar que nos mangues e nas águas do Amazonas e do Orenoco há mais mosquitos e sezões do que inspiração, que na floresta há insetos repulsivos, répteis imundos, que a pele furta-cor do tigre não tem o perfume das flores - que tudo isto é sublime nos livros mas é soberanamente desagradável para quem os enfrenta.

Para Marques (2006: 175), o indianismo dentro do anseio romântico por uma literatura nacional, foi o mais bem sucedido passo nessa direção, pois, com sua normatização, a literatura brasileira deu vida a um símbolo que, sem colocar em perigo a realidade escravocrata, desempenhou uma missão importante ao se contrapor, no plano das representações, a imagem do colonizador luso que deveria ser desprezada, pelo menos em público. Na realidade, o indianismo brasileiro é uma recriação a partir do indianismo francês, nas palavras de Coutinho (1969: 70): “imitávamos, através do francês, o que já era nosso; o que já estava na origem da nossa história literária." Para entendermos esta evolução, o indianismo brasileiro nasce com Anchieta, que denominamos de Indianismo Barroco, que deixou sua obra numa mescla de latim, português, castelhano e tupi (Coutinho, 1969: 65). Numa segunda fase que denominamos Indianismo Arcádico (Coutinho, 1969: 67-68) temos Basílio da Gama 
baseando-se num motivo histórico para exaltar os portugueses e atacar os jesuítas na luta contra os índios das missões, conquanto vencidos os aborígenes, o poeta lhes celebra com intrepidez. Já Santa Rita Durão se apegou ao modelo camoniano, cujo poema Caramuru é escrito em oitava rima, e faz ainda um reparo ao português, quando afirma que "os sucessos do Brasil não mereciam menos que os da índia." Numa terceira fase passamos pelo Indianismo exótico, importado (Coutinho, 1969: 68), onde um grupo principalmente de franceses, como Thevet, Jean Léry, Claude d'Abeville narram as singularidades admiráveis dos nossos índios, que eram gente "bestial, de pouco saber e por isso tão esquiva." Poderíamos encontrar essa singularidade no poema gonçalvino Tabira, em que o chefe indígena fazia com que os lusitanos dormissem tranqüilos na fé do tratado. Apesar de tudo e das informações que os artistas lusos tiveram, não houve nenhum indianista português, Coutinho (1969: 70) destaca que além do Pd. Anchieta, Pd. Manuel da Nóbrega, Pd. Fernão Cardim, Pero Lopes de Souza, Gabriel Soares, Gândavo estavam entre aqueles que escreveram noticias a respeito do aborígene brasileiro. Nem com o mito do bom selvagem que rondou a Europa nos séculos XVII e XVIII os artistas portugueses se aventuraram a escrever sobre nossos índios.

Coube aos poetas brasileiros pós independência criarem um indianismo, que surge com Gonçalves de Magalhães, depois com Teixeira de Souza chegando ao seu apogeu com Gonçalves Dias (Coutinho, 1969: 72). Gonçalves surge desconstruindo a visão colonialista acerca do universo nativo, valorizando e identificando-se com o que antes fora repudiado (Oliveira, 2005: 40), porque ainda que os índios despertassem a curiosidade dos primeiros cronistas portugueses, estes viam seus costumes como diabólicos e que careciam de civilizar-se. Gonçalves Dias não teve o seu indianismo ligado ao mito do bom selvagem, que despertou via Montaigne, as idéias que culminaram em Rousseau, pai do romantismo; o maranhense lhe é contrário, substitui a ideologia pela realidade humana do índio (Coutinho, 1969: 74). Contudo, entre outros 
fatores, o Brasil sempre esteve ligado à França como sua metrópole cultural (Kothe, 1997a: 34); embora para Souza Pinto (1928: 4) Brasil e Portugal são indiscutivelmente duas literaturas camonianas. Deve ser por isso que para Kothe (1997a: 34) no Brasil a literatura é parte constitutiva da definição da identidade nacional fora do país como um documento de uma cultura mais ou menos exótica e estranha.

Mas entremos as características desse indianismo europeizado, mas antes de dizermos qualquer coisa é preciso deixar claro, os índios não prestavam nenhum culto organizado a deuses e heróis (Bosi, 2001: 68). Na arte da pregação o missionário se volta para o índio, e prega-lhe em tupi e compõe autos devotos com o fim de convertê-lo. O salvacionismo ibérico surge porque para eles a vida do selvagem estava imersa na barbárie e as suas práticas se inspiravam diretamente nos demônios (Bosi, 2001: 92). Na tentativa de fazer-se entendido pelos índios, os primeiros jesuítas fizeram uma transliteração das divindades católicas para as divindades indígenas. Na verdade isto é uma tática antiga no exercício da pregação, no Novo Testamento, por exemplo, vemos a imagem de Hades aparecer por dez vezes (Mateus 11:23; 16:18; Lucas 10:15; 16:23; Atos 2:27, 31; Apocalipse 1:18; 6:8; 20:13, 14) na imagem do inferno. Anchieta, tido como o primeiro apóstolo do Brasil, utiliza termos indígenas no ato da pregação, com isto, PaiGuaçu (Pai maior) quer dizer Bispo, Tupansy (mãe de Tupã) é Nossa Senhora, Tupãóka (casa de Tupã) é a igreja, Tupãretama (terra de Tupã) é o reino de Deus, Anhangá (protetor da floresta) é o demônio; Tupã (dominador dos raios) é Deus; Karaibebé (profeta voador) é a figura bíblica de anjo; e anga (que vale tanto para sombra quanto para o espírito dos antepassados) é o equivalente de alma. Essa recriação de Anchieta é denominada por Bosi (2001: 65) de mitologia paralela. No entanto, Tupã na explicação de Bosi é talvez o nome onomatopaico, de uma força cósmica identificada com o trovão, fenômeno celeste que teria ocorrido a primeira vez com o arrebentamento da cabeça de uma personagem mítica, Maíra-Monã. De qualquer modo causa certa estranheza fundir 
o nome de Tupã com a noção do Deus tri-uno, ao mesmo tempo todo-poderoso, o espírito santo e o vulnerável Filho do Homem dos evangelhos.

Segundo Bornheim (1993: 110), a mitologia clássica fora a fonte na qual nutria toda a arte dos gregos, e que por isso os modernos também precisavam de uma mitologia que pudesse alimentar a imaginação poética, inaugurando uma nova simbólica para a arte moderna. A mitologia grega surgiu como que da terra, de uma espontaneidade popular que fazia a sua vigor, ao passo que os românticos não podiam esperar uma mitologia da geração espontânea, por isso precisam provocar e elaborar como uma obra de arte, a partir desse pressuposto é que encontramos o indianismo gonçalvino. A religião recriada por Gonçalves Dias nasce com o intuito de resgatar as divindades indígenas reconstituídas pelos jesuítas. No entanto, Gonçalves não recupera a forma original destas divindades, mas recupera as na forma em que foram reconstituídas, o que temos não é a recuperação do mito em si, mas a restauração da divindade sem a sua forma original.

Podemos ainda analisar pelo prisma de Bornheim (1993: 109), que afirma que os românticos pretendiam era "um novo catolicismo; nessa nova religião a unidade entre o mundo espiritual e o natural deveria ainda ser mais acentuada." Basicamente, Gonçalves recupera as divindades indígenas com todas as formas católicas atribuídas pelos Jesuítas, e a partir disso reconstrói um imaginário religioso segundo os pressupostos da religião romana, a imagem de Tupã com o denso velâmem de penas é, por exemplo, de Jeová calado diante da calamidade de Job, mas no caso deste há uma resposta ao final, porque é resgatado de sua ruína, enquanto os índios não conseguem a mesma façanha.

Porque as flechas do Todo-Poderoso estão em mim, cujo ardente veneno suga o meu espírito; os terrores de Deus se armam contra mim (Job, 6:4). 
“Anhangá impiedoso nos trouxe de longe

Os homens que o raio manejam cruentos,

Que vivem sem pátria, que vagam sem tino

Trás do ouro correndo, voraces, sedentos.

E a terra em que pisam, e os campos e os rios

Que assaltam, são nossos; tu és nosso Deus:

Por que lhes concedes tão alta pujança,

Se os raios de morte, que vibram, são teus?"

Há um fator que devemos considerar, a narrativa bíblica trata-se de um ambiente bastante rudimentar, Job é um camponês e pelo número de seus bens "sete mil ovelhas, três mil camelos, quinhentas juntas de bois e quinhentas jumentas" (Job, 1:3) percebemos que trata-se de uma época bastante remota. $\mathrm{O}$ ambiente indianista é por natureza bastante mais rudimentar que os termos estabelecidos pela civilização européia. Se observarmos as narrativas homéricas retrata de tempos idos do início da civilização, assim sendo, a Ilíada é, portanto o primeiro retrato da união de comunidades urbanas naquilo que é de seu interesse para levar a cabo uma guerra. Nas citações acima o que vimos é um patriarca israelita queixando-se de ter recebido maior castigo do que merecia, e que as flechas de seu deus haviam lhe atingido, do outro lado surge o centenário indígena queixando-se dos raios de morte lançados pelos filhos de Anhangá, que, no entanto estes raios eram de Tupã, o que se pode concluir que este permitia seus filhos sofrer enquanto tinha a sua cabeça coberta por um denso velâmem. Mas Job desfruta daquilo que os índios em Deprecação não puderam desfrutar, a resposta final para seus questionamentos:

Brasiliana - Journal for Brazilian Studies. Vol. 2, n.2 (Nov 2013). ISSN 2245-4373. 
"Cinge agora os teus lombos como homem; eu te perguntarei, e tu me explicarás.

Porventura também tornarás tu vão o meu juízo, ou tu me condenarás, para te justificares?" (Job, 40: 7,8).

O exemplo básico de que Gonçalves dias ao apossar-se das divindades indígenas reivindica-as pode ser visto em Tabira.

“É Tabira - cruel, inimigo,
Já nem crê, renegado, em Tupã!"

Esta referência indica que Tabira, aliado dos portugueses, convertido ao catolicismo não era mais um cultor de Tupã. Tabira sugere que os portugueses utilizaram-se da propagação de sua religiao para debilitar os cultos nativos e corromper valores culturais que antes eram compartilhados entre membros de tribos diversas, dando-lhes certa unidade (Oliveira, 2005: 51). Mas não há diferença entre Tupã e o deus católico, pelo menos não na essência, a diferença que se estabelece entre ambos não é frisada pelo poeta, mas basicamente estava na diferença entre estes povos, em que os portugueses eram filhos de Anhangá. Isso leva-nos a uma indagação, porventura os índios não foram vistos como gente pagã a quando da chegada dos portugueses? A todo instante os jesuítas não deixavam de ver os costumes indígenas como uma deturpação e influências malignas. Gonçalves não reivindica Tupã e Anhangá para devolver-lhe aquilo que tinham tido, mas para dar aos índios uma religião a que nunca tiveram.

A respeito de lendas e do fabulário indígena, Coutinho (1969: 89) e Ricardo (1964: 62) indagam por que não os teria Gonçalves melhor aproveitado. Num dos fragmentos 
póstumos, Poema Americano, Gonçalves tentou explorar uma das lendas da teogonia tupi, também tentou reproduzir no controverso poema Mãe D'água. Mas o que Coutinho evidencia é o fato do maranhense destruir um dos nossos mitos: o da amazonas, o que a princípio parece paradoxal, pois todo poeta é um criador de mitos. Motivados pelos testemunhos de Orellana e Cristóvão da Cunha, o Instituto Histórico tentou descobrir a veracidade dos fatos, Gonçalves por sua vez, tratou de concluir com a inexistência das mulheres prodigiosas, foi uma afirmação definitiva, histórica, sociológica e até biológica, como concordaria muitos críticos.

A verdade é que se Gonçalves destruiu um mito, terá criado muitos outros (Coutinho, 1969: 90) Como, por exemplo, o mito do sabiá que canta nas palmeiras, porque de fato o sabiá das palmeiras não canta. Gonçalves apossa-se da mitologia paralela criada pelos jesuítas para diferenciá-la, é uma contradição, talvez a maior entre todas as muitas que o poeta terá tido, mas atribuir uma religião aos índios semelhante ao cristianismo é de fato uma verdade poética pra lá do que imaginávamos, porque a noção de Tupã como vimos é bastante diversa da imagem do Deus israelita. O culto a Tupã estabeleceu algo novo para os indígenas, porque Anhangá ganha as características anti-Tupã (Bosi, 2001: 66).

Outro elemento controverso é a antropofagia indígena, mas quanto a isto Gonçalves teria sido o mais fiel de todos, porque em seu poema mais célebre I-Juca Pirama traz um retrato de um sacrifício enaltecendo o costume, porque este na realidade tinha um caráter mágico, servia como punição da injúria e da profanação do caráter sagrado do Nós coletivo (Fernades, 1989: 236). Somente os maus, efeminados e os covardes consumiam-se na danação eterna. Anhangá atormentaria aqueles que não haviam vivido de acordo com os bons costumes, que não tivessem mostrado valor nas guerras, ou aprisionado numerosos inimigos, sacrificando-os ritualmente (Fernandes, 1989: 164), o filho havia se demonstrado imbele e fraco diante da morte. Léry (1941: 177)

Brasiliana - Journal for Brazilian Studies. Vol. 2, n.2 (Nov 2013). ISSN 2245-4373. 
havia observado que o prisioneiro estava longe de mostrar-se pesaroso diante destes rituais de antropofagia e que o mesmo comportamento se fazia entre as mulheres (id.: 179). Segundo Bosi (2001: 67), no universo escuro de Anhangá perfila os maus hábitos, tais como a antropofagia, a poligamia, a embriaguez pelo cauim e a inspiração do fumo queimado nos maracás. No entanto, na cultura indígena, a devoração ritual do inimigo remetia, na verdade, a um ato de teor eminentemente sacral que dava aos que celebravam uma nova identidade e um novo nome. Se por um lado aquele que celebrava buscava com isso vingar os mortos, do outro estava aquele que ia morrer pela honra de sua tribo. A vingança é imprescindível numa tribo indígena americana (Fernandes, 1989: 262). Por menos que sejam ultrajados, jamais the perdoarão a ofensa. Esta obstinação adquire e conserva os índios, de pais a filhos (Fernandes,1989: 262).

Mas nem por isto o poeta deixou de ousar na inovação poética em I-Juca Pirama. Neste poema, o poeta inventou um recurso inesperado e excelente: o lamento do prisioneiro, caso único em nosso indianismo, que rompe a tensão monótona da bravura tupi graças à supremacia da piedade filial:

\section{“Guerreiros, não coro \\ Do prato que choro."}

Esta inovação poética, e que não encontramos nas narrativas histórias dos primeiros cronistas é algo bastante presente nas obras literárias, poderíamos observar os lamentos de Enéias e o pedido de morte diante das peripécias que enfrenta, bem como a tristeza de não haver sucumbido junto as muralhas de Tróia, antes coube-lhe o triste destino de povoar uma nova terra, construir a nação romana. O troiano deplora, chora, mas ao cabo de tudo acaba por seguir os desígnios dos deuses, basicamente o que acontece com o herói do poema gonçalvino. Este lamento, ou seja, a primeira tentativa de escapar do 
destino cruel e nu é bastante evidente nas tragédias gregas, em todas elas ao cair em si do destino irremediável que lhe aguarda, o personagem tenta sobrepor-se primeiro para depois aceitar aquilo que lhe foi imputado, e porque ainda não assemelharíamos o lamento na obra com as palavras de Cristo no Getsêmani quando buscava pela vez derradeira escapar de seu destino, mas que acaba cedendo à vontade do Pai, tal como o jovem Tupi que cede diante do desejo do pai.

Tendo em vista estes relatos, diríamos que a reconstrução da Ilíada Brasileira, aquilo que o poeta denomina de "criação recriada", o é de fato, e seria demasiado afirmamos que sua inovação poética seja de fato uma inovação porque o próprio poeta já havia percebido seu limite, o duelo central de Os Timbiras é um retrato de um duelo das epopéias gregas e latinas; a negação de Camões é a própria denúncia da influência que esta pode causar; e para além, a inovação aparente em I-Juca Pirama que já estava nas tragédias gregas; porque não citarmos Tabira que cravejado de setas caminha contra as hostes inimigas semelhante a um guerreiro Aqueu dentro da Ilíada. Deve-se ainda levar em conta, que nem mesmo ao optar pelo índio como elemento genuinamente nacional, nem assim o poeta teria inovado, porque tantos outros o fizeram antes, até mesmo Caminha, porque o índio já estava de alguma forma citado no primeiro relato escrito no Brasil. Se Gonçalves foge dos conceitos do "bom selvagem" não consegue escapar dos conceitos de nobreza européia atribuindo-os aos nativos indígenas.

Aliás, o Gonçalves Dias que critica tão veemente a América de se ter tornado cópia da Europa, também é uma imitação do tipo de poeta que o Velho continente produzia. Num dos quadros mais belos d'Os Timbiras, nomeadamente no canto América infeliz há uma passagem onde percebemos porque Gonçalves teria construído a imagem de um Portugal envelhecido e de um Brasil juvenil.

Brasiliana - Journal for Brazilian Studies. Vol. 2, n.2 (Nov 2013). ISSN 2245-4373. 
“América infeliz! - que bem sabia,

Quem te criou tão bela e tão sozinha,

Dos teus destinos maus! Grande e sublime

Corres de pólo a pólo entre os sois mares

Máximos de globo: anos da infância

Contavas tu por séculos! que vida

Não fora a tua na sazão das flores!

Que majestosos frutos, na velhice,

Não deras tu, filha melhor do Eterno?!

Velho tutor e avaro cubiçou-te,

Desvalida pupila, a herança pingue

Cedeste, fraca; e entrelaçaste os anos

Da mocidade em flor - às cãs e à vida

Do velho, que já pende e já declina

Do leito conjugal imerecido

À campa, onde talvez cuida encontrar-te!"

Transcrevo-vos abaixo os relatos de Alexandre Herculano (1998: 97-98), deixando-vos o fino faro da crítica para a estética da recepção falar-vos aos ouvidos:

“Portugal é o velho aborrecido e triste, que se volve dolorosamente no seu leito de decrepidez; que se lamenta de que os raios do sol se tornassem frouxos, de que se encurtassem os horizontes da esperança, de que um crepe fúnebre vele a face da terra. Perguntai, porém, ao povo infante, que cresce e se fortifica além dos mares, que se atira ridente pelo caminho da vida, se é verdade isso que diz o ancião na tristeza do seu 
vegetar inerte, e que, encostado na borda do túmulo, deplora, pobre tonto, o mundo que vai morrer!

(...) Nós somos hoje o hilota embriagado, que se punha defronte da mesa nas filitias de Esparta, para servir de lição de sobriedade aos mancebos. O Brasil é a moderna Esparta, de que Portugal é a moderna Helos."

Para Souza Pinto (1928: 5) o indianismo era uma tentativa, uma realização fecunda do nacionalismo americano, um produto literário tentando transpor às tradições heróicas e mitológicas da Europa, com uma mitologia e um heroísmo americano. E falemos d'Os Timbiras, aclimatado ao redor da linha do Equador, esse poema americano foi na verdade uma poesia brasileira, e por mais que insistisse colocando os Andes, o lhama, o condor, o Piaga, os Manitôs, etc., por mais que se lembrasse das naus da Holanda, dos galeões de Espanha, das fragatas de França e das caravelas portuguesas, se esquece de um Mayflower da Inglaterra e os povos Europeus citados são apenas aqueles que intervieram na colonização do Brasil. Mister ainda, estes povos se restringiram ao nordeste brasileiro, a região da província natal de Gonçalves Dias. Os seus Timbiras e Gamelas habitavam o vale do Mearim e estavam longe de ser belicosos como os Tupinambás e Aimorés. Mas isto não importa! Nenhuma tribo poderia representar todas as outras sem ser contestada. A Confederação dos Tamoios de Gonçalves de Magalhães tomou um rumo muito maior historicamente - mas de que importa a história para a ficção? Gonçalves Dias não falhou na sua eleição e na preparação de sua arte. Os Timbiras representam todos os povos indígenas com a mesma autoridade que o Brasil pode representar todos os países americanos, porque no fundo são uma coisa só, passaram todos pelos mesmos processos. Quando o poeta compara os povos europeus e americanos sente uma dor fria e aguda, um sentimento de inferioridade, de incapacidade, por assim dizer. Mas na Eneida, por exemplo, esta inferioridade surge no 
poder de Virgílio em fazer a sua história ao mesmo tempo real e vivida, em parte, de uma inferioridade de seu temperamento próprio, e em parte da adaptabilidade inferior da vida de sua própria idade para tratamento imaginativo. Para muitos teóricos o contraste entre Homero e a vida de Virgílio é fundamental para a inferioridade do poema. Ou seja, o que mais poderíamos esperar de um cantor ciente da sua inferioridade racial e social? A sua consciência de somenidade incluía o sentimento de ser o primeiro poeta nacional, portanto sem um predecessor, do mesmo modo, ainda lhe pesava a sombra de um Camões no além-mar.

A morte de Gonçalves Dias - com um livro inacabado e fracassado em seu intento de voltar à pátria - adquire, no texto machadiano, amplas ressonâncias simbólicas, ligadas à impossibilidade de fechamento do ciclo, tal como ocorre nas travessias épicas. Para grifar tais ligações, Machado lança mão de um contraponto e inicia o seu poema, evocando a vida de Luís de Camões (Longo, 2006: 44). Se Camões tem grandeza épica, exemplificando o melhor da sua coletividade, Gonçalves Dias é o mais infeliz, dentre os infelizes; estigmatizado pela singularidade do seu destino, é ele vítima, em meio a um périplo que não se completou (Longo, 2006: 45). Junto com o grande projeto de Os Timbiras, morre também o grande projeto da fundação de uma identidade literária brasileira nos moldes que os próprios europeus imaginavam, tal como Herculano aconselha o jovem poeta a se desvincular do patronato europeu, tal como Denis acredita que os brasileiros poderiam inclusivamente ser mestres dos europeus, porque seriam grandes como os europeus, exatamente por serem diferentes destes.

Essa fundação livre é impossível, porque se apercebermos bem, a idéia fixada e evidenciada por Rouanet(1991: 245) de que seja por afirmação, seja por negação, este é o lugar onde o Brasil é o mais que os outros países, o único dentre todos. Invariavelmente, poderíamos voltar as narrativas épicas e de lá extrairíamos adventos poéticos idênticos, basta-nos olhar para as canções do exílio que Ovídio pronunciara, quando esteve 
exilado da sua pátria nos confins do Império, na terra dos bárbaros romenos. Poderíamos ainda olhar para o rapsodo grego, cujas narrativas prefiguram-se como o cerne do surgimento da literatura ocidental, o que está no fundo da Odisséia, por exemplo, é o retorno do desesperado herói que não se cansa, nem se deixa enganar pelas gabarolices de outras terras, haja vista que se fizermos um olhar profundo para a terra natal de Odisseu, Ítaca não apresentava nenhuma atratividade como o rapsodo grego descreve noutras regiões, as descrições resumidas da montanhosa Ítaca são indícios da sua limitação e importância, mesmo assim, é pra lá que o herói se aventura no seu regresso, preferiria morrer ao pé das muralhas de Tróia do que vagabundo andar por outras terras sem jamais regressar a sua. Mas o que não acontece na Odisséia, vir-nos-ia a nós mais tarde, nas palavras de Enéias a angústia de perder a pátria, de saber que não há regresso. Muitas vezes o herói invocou a morte, e desejou ter morrido junto das muralhas da cidade.

Para Souza Pinto (1928: 22), é com Os Timbiras que o indianismo atingiu seu apogeu. De acordo com Henriques Leal, entre outras produções literárias Gonçalves Dias trazia consigo, na viagem para o Brasil, os dez cantos inéditos de Os Timbiras. De acordo com Moisés (1989: 36) ${ }^{8}$, a epopéia teria dezesseis cantos que constituíam ao todo três anos de labor, mas o poeta naufraga e com ele sua obra (Ackermann, 1964: 27). Reza a lenda que Camões (Ackermann, 1964: 134) nadou para salvar a sua primeira versão de Os Lusíadas, do outro lado o poeta brasileiro não teve a mesma sorte, não escapando nem a própria vida, deixando do seu legado uma quantidade relativamente diminuta de poesias, pela brevidade da vida, pela morte trágica. A estilização nostálgica é o caráter central de toda esta narrativa épica, os versos do poeta de per si contêm suspiros de saudades de tempos passados, de lugares queridos que nunca se hão-de rever, de florestas devastadas e de uma civilização que se extinguiu. Segundo Ackermann (1964: 114), o

8 Também de acordo com Coutinho (1986: 86), Ricardo (1964: 66) e Cândido (1993: 85).

Brasiliana - Journal for Brazilian Studies. Vol. 2, n.2 (Nov 2013). ISSN 2245-4373. 
pessimismo cultural é talvez o sentimento que terá inspirado ao poeta este protesto. O pessimismo cultural era algo bastante forte na vida de Gonçalves Dias e que estava arraigado na sua própria condição humana, segundo Bandeira (1998a: 24) o poeta era um misto entre o otimismo e o pessimismo:

"Mas aquele homenzinho de um metro e cinqüenta, que em versos moles ou na correspondência íntima, tanto se queixava, e remoendo a sós os seus desgostos emprestava-lhes as proporções de irremediáveis desgraças, crescia muito acima do estalão comum nos atos de sua vida, sempre reveladores de forte vontade, sereno estoicismo e extraordinária resistência. Em agosto falava de suicídio, e no mês seguinte empenhavase nas eleições municipais em favor de seus amigos cabanos."

Entre outros relatos, as cartas de Gonçalves Dias, o fluxo de inferioridade expresso em suas poesias dão-nos a dimensão do quanto o poeta sentia-se raso. Gonçalves traz isso para seu conjunto de obras indianistas, denomina-se "humilde cantor de um povo extinto". Com seu pessimismo, com o declínio dos poemas longos, com a consciência da impossibilidade de se fazer uma literatura independente das literaturas exteriores, com a consciência de que o índio não poderia ocupar sozinho o lugar central da literatura, com a morte do poeta, o próprio Machado (1962: 803) diz que o índio não deve ser o patrimônio exclusivo da literatura, mas nem por isso deve ser o objeto excluído da literatura. Os Timbiras ficaram assim, para sempre inacabado e o único modo de saber o que se passava nos cantos perdidos é através dos relatos de Henriques Leal, o que não é fiável, porque não se trata de um fragmento do autor, mas de um relato de um leitor.

De fato o indianismo gonçalvino, difundido no século XIX é originário do século XVIII e XVII com o seu amor ao exótico e o naturismo de Rousseau, entre outros, 
principalmente franceses. Porém, o indianismo, surgira, no século XVII, conforme ressalta Souza Pinto (1929: 24), com um autor, de quem nada mais sabemos Diogo Grasson Tinoco, compusera em 1629 um poema que lamentavelmente encontra-se perdido, sobre o descobrimento das esmeraldas por Fernão Dias Pais. Deste poema restou-nos quatro oitavas no poema Vila Rica de Cláudio Manuel da Costa. Para Souza Pinto (1931: 12), indianismo foi uma verdadeira declaração de amor a pátria, que tem uma visão entristecida e aformoseada da pátria tropical, e de longe o indianismo gonçalvino o mais autêntico de todos. O índio de Gonçalves Dias não é mais autêntico do que o de Magalhães ou o de Norberto pelas circunstâncias de ser mais índio, mas por ser mais poético, como é evidente, segundo Cândido (1993: 75), em I-Juca Pirama.

Já analisamos noutra ocasião a influência da epopéia latina na obra de Gonçalves Dias $^{9}$; de fato não se deve falar em literatura pura, sem recepção, após o advento das obras homéricas, porque todas passam pelo crivo destas, seja pela aceitação ou pela negação. A influência portuguesa é indisfarçável, é no conselho de Alexandre Herculano que se fia o de não imitar os portugueses; ou seja, segue o conselho de um português para escrever daquilo que este acha ser-lhe alheio; mas se os franceses Saint Pierre e Chateaubriand são indianistas, porque não ser um brasileiro? É daí que a influência francesa há de vir sobre Gonçalves Dias (Coutinho, 1969: 111). O poeta frequentou o meio português em Coimbra, a influência do seu lirismo é puramente garrettiano, Herculano já teria aberto uma lacuna ao afirmar que o poeta tem muito de português na sua poética, estudando italiano conhece Tasso, Ariosto, Dante, Petrarca; conhecendo alemão e fazendo-se tradutor de Heine, Schiller; entre os franceses torna-se amigo de Ferdinand Denis, Ackermann enumera ainda Lamartine, Victor Hugo, Gautier, Musset e Sainte-Beuve (Coutinho, 1969: 112). Para Franchetti (2007: 55), o enorme prestígio do

\footnotetext{
${ }^{9}$ A dimensão anti-épica de Virgílio e o Indianismo de Gonçalves Dias, Coimbra, Centro de Estudos Clássicos e Humanísticos, 2011.
}

Brasiliana - Journal for Brazilian Studies. Vol. 2, n.2 (Nov 2013). ISSN 2245-4373. 
escritor português juntado ao comentário, valeu na época como batismo do nascimento da poesia nacional brasileira.

Longe da pátria ausente, cantou, envernizou, amenizou, poetizou enfim os costumes ingênuos, as festas inocentes e singelas, as guerras heróicas, a resignação sublime, e a morte corajosa, bem como os trajes elegantes, e as decorações pomposas dos nossos selvagens. E eis aí todo mundo a compor-se e menear-se a exemplo e feição dos reis, e aturdindo-nos em prosa e verso com tabas, muçuranas, janúbias e maracás (João Francisco Lisboa, Apud Cândido, 1993: 19). Depois do fundador do romance brasileiro e do poeta que melhor cantou a terra e o índio e que melhor situou os tempos os grandes temas de todos os tempos na arte poética, o indianismo declinaria (Sodré, 1969: 284). Machado de Assis, consciente da impossibilidade da literatura indianista tentou ainda sem sucesso prosseguir com a poética indianista, no entanto em vão. O Brasil jamais veria a sua identidade desligada de Portugal e por mais que dos lusos se distancie sempre há de se lembrar que na sua meninisse alimentou-se nos seios da velha nação que o próprio Gonçalves Dias reconheceu: o Brasil é uma nação cuja base tem os frios ossos da nação senhora, e por cimento a cinza profanada dos indígenas, amassada pelos pés dos escravos africanos (Tim 3.69-72). Essa é sem dúvida a nossa verdadeira identidade.

\section{Bibliografia}

Ackermann, Fritz. A obra poética de António Gonçalves Dias. São Paulo: Conselho Estadual de Cultura, 1964.

Aldé, Lorenzo. "À procura de Pedro II". In: Revista de História da Biblioteca Nacional 86 2012, pp. 16-23.

Athayde, Tristão de. “Gonçalves Dias, o crítico”. In: O Jornal Rio de Janeiro. 1923, Ago. 14.

Brasiliana - Journal for Brazilian Studies. Vol. 2, n.2 (Nov 2013). ISSN 2245-4373. 
Asanha, Gilberto. A Forma Timbira: estrutura e resistência. São Paulo: USP, FFLCH, 1984.

Assis, Machado de. Obra completa de Machado de Assis. Rio de Janeiro: Nova Aguilar. Vol. III, 1994.

Bandeira, Manuel. "A Vida e a Obra do Poeta". In: Dias, Antônio Gonçalves. Gonçalves Dias: Poesia e prosa completas. Organização Alexei Bueno. Rio de Janeiro: Nova Aguilar, 1998a, pp. 13-56.

Bandeira, Manuel. "A Poética de Gonçalves Dias". In: Dias, Antônio Gonçalves. Gonçalves Dias: Poesia e prosa completas. Organização Alexei Bueno. Rio de Janeiro: Nova Aguilar, 1998b, pp. 57-70.

Berredo, Bernardo Pereira de. Annaes historicos do Estado do Maranhaõ, em que se da' noticia do seu descobrimento, e tudo mais que nelle tem succedido desde o anno em que foy descuberto até o de 1718. Org. Carlos de Araújo Moreira Neto, Iquitos, Quito:

IIAP-CETA, Ediciones Abyaa-Yala, 1989 (Fac. Similar da ed. Lisboa, Officina de Francisco Luiz Ameno, 1749).

Biblia. Trad. por Monges Beneditinos de Maredsous Belgica. Bíblia Ave Maria, 1970.

Bornheim, Gerd. “Filosofia do romantismo". In: Guinsburg, J. O Romantismo. São Paulo: Editora Perspectiva, 1993, pp. 75-111

Bosi, Alfredo. Dialética da colonização. $4^{a}$ Ed. São Paulo: Companhia das Letras, 2001

Bosi, Alfredo. "Imagens do Romantismo no Brasil". In: Guinsburg, J. O Romantismo. São Paulo: Editora Perspectiva, 1993, pp. 239-256

Brandão, Ambrosio Fernandes. Diálogos das grandezas do Brasil, segundo a edição da Academia Brasileira, corrigida e aumentada, com númerosas notas de Rodolfo Garcia, e int. de Jaime Cortesão. Rio de Janeiro: Dois Mundos, 1943.

Candido, Antonio. Formação da literatura brasileira: momentos decisivos. Volume II. $7^{\mathrm{a}} \mathrm{Ed}$. Belo Horizonte: Editora Itatiaia, 1993.

Coutinho, Afrânio e Coutinho, Eduardo de Faria. A literatura no Brasil. Vol.II Rio de Janeiro/Niterói: José Olympio/ EDUFF, 1969. 
Dias, Antônio Gonçalves. Gonçalves Dias: Poesia e prosa completas. Org. Alexei Bueno, Rio de Janeiro: Nova Aguilar, 1998.

Dias, Antônio Gonçalves. Obras posthumas de A. Gonçalves Dias. 6 Vls. Org. Antônio Henriques Leal, São Luís, B. de Matos, 1868.

Dias, Antônio Gonçalves. O Brazil e a Oceania. Rio de Janeiro: H. Garnier, 1909.

Fernandes, Florestan. A organização social dos Tupinambá. São Paulo: Hucitec -UNB, 1989.

Franchetti, Paulo. Estudos de literatura brasileira e portuguesa. Cotia: Ateliê Editorial, 2007.

Herculano, Alexandre. "Futuro Literário de Portugal e do Brasil". In: Dias, Antônio Gonçalves. Gonçalves Dias: Poesia e prosa completas. Org. Alexei Bueno. Rio de Janeiro: Nova Aguilar, 1998, pp. 97-100.

Kothe, Flávio. O cânone colonial. Brasília: Editora da Universidade de Brasília, 1997a.

Kothe, Flávio. O cânone imperial. Brasília: Editora da Universidade de Brasília, 1997b.

Koster, Henry. Viagens ao nordeste do Brasil. Trad. Luiz da Camara Cascudo. São Paulo: Cia Editora Nacional, 1942.

Ladeira, Maria Elisa "Uma Aldeia Timbira”. In: Novaes, Sylvia Caiuby. Habitações Indígenas. São Paulo: Editora Nobel, 1982, pp. 12-31.

Leal, Antonio Henriques. Pantheon Maranhense: Ensaios bibliográphicos dos maranhenses illustres já falecidos. T. 3. Lisboa: Imprensa Nacional, 1874.

Léry, Jean de. Viagem à terra do Brasil. Trad. integral e notas de Sérgio Milliet. São Paulo: Livraria Martins, imp., 1941.

Longo, Mirella Márcia. “Guerreiros sem canto”. In: Letras de Hoje 4, 2006, pp. 41-57.

Marques, Wilton José. Gonçalves Dias: o poeta na contramão: literatura e escravidão no romantismo brasileiro. São Carlos: EduFSCar, 2010.

Brasiliana - Journal for Brazilian Studies. Vol. 2, n.2 (Nov 2013). ISSN 2245-4373. 
Marques, Wilton José. “O índio e o destino atroz". In: Letras \& Letras 22, 2006, pp. 175191.

Marques, Wilton José. “Revista e Ruptura”. In: II Cochillr - Anais, 14, 2003, pp. 1-8.

Melatti, Júlio Cezar. Indios do Brasil. 7ª̣ ed. São Paulo: Hucitec - USP, 1993.

Miguel pereira, Lúcia. A vida de Gonçalves Dias (contendo o Diário inédito da viagem de Gonçalves Dias ao Rio Negro). Rio de Janeiro: José Olympio Editora, 1943.

Moisés, Massaud. História da literatura brasileira. 2ª ed. São Paulo: Cultrix, 1989.

Oliveira, Andrey Pereira de. "A corrupção do universo indianista nas "poesias americanas" de Gonçalves Dias". In: Revista Trama, 2, 2005, pp. 39-57.

Ricardo, Cassiano. O indianismo de Gonçalves Dias. São Paulo: Conselho Estadual de Cultura, 1964.

Ricoeur, Paul. "Life in quest of narrative". In: Wood, David. On Paul Ricoeur: narrative and interpretation. Londres: Routledge, 1991, pp. 20-33.

Rouanet, Maria Helena. Eternamente em berço esplêndido: a fundação de uma literatura nacional. São Paulo: Siciliano, 1991.

Sayers, Raymond. O negro na literatura brasileira. Rio de Janeiro: O Cruzeiro, 1958.

Sodré, Nélson Werneck. História da literatura brasileira. Rio de Janeiro: Civilização Brasileira, 1969.

Sodré, Nélson Werneck. A formação da sociedade brasileira. São Paulo: Livraria José Olympio Editora, 1944.

Souza Pinto, Manuel de. O indianismo na poesia brasileira. Coimbra, 1928

Souza Pinto, Manuel de. Gonçalves Dias em Coimbra. Coimbra: Coimbra Ed., 1931.

Torres-Homem, F. S. "Considerações economicas sobre a Escravatura". In: Nitheroy, Revista Brasiliense, 1 T.1, 1836, pp. 35-82. 
Vasquez, Pedro Afonso. "A imagem da capa". In: Revista de História da Biblioteca Nacional, 86, 2012, 4. 